\title{
KULTURA STRATEGICZNA JAPONII
}

\author{
Agata Ziętek \\ Uniwersytet Marii Curie-Skłodowskiej, Wydział Politologii, \\ Zakład Stosunków Międzynarodowych \\ e-mail: wiktoriazietek@gamil.com
}

\begin{abstract}
Streszczenie: Celem artykułu jest zwrócenie uwagi na rolę Japonii w kształtowaniu się nowego ładu międzynarodowego w regionie Azji i Pacyfiku, przez pryzmat jej kultury strategicznej. Konieczne jest zatem udzielenie odpowiedzi, czy z racji swej potęgi gospodarczej i technologicznej Japonia jest predysponowana do odgrywania roli pełnowymiarowego mocarstwa? Czy odgrywanie takiej roli jest ograniczane przez kulturę strategiczną Japonii? Jakie były w przeszłości i jakie są obecnie uwarunkowania jej kultury strategicznej? Przyjmuję następującą tezę: kultura strategiczna Japonii zmienia się mimo wewnętrznego instytucjonalnego antymilitaryzmu.
\end{abstract}

Slowa kluczowe: kultura strategiczna, Japonia, Shinzō Abe, instytucjonalny antymilitaryzm, proaktywny pacyfizm

\section{WSTĘP}

Od jakiegoś czasu jesteśmy świadkami dyskusji dotyczącej nowego międzynarodowego ładu w regionie Azji i Pacyfiku. W dyskusji tej pojawia się pytanie dotyczące zarówno roli Stanów Zjednoczonych, Chin, Rosji, Indii czy Australii oraz tego jakie miejsce w nowym układzie sił przypadnie państwom ASEAN, państwom koreańskim, czy wreszcie Japonii?

Rolę międzynarodową określa się uwzględniając działania podejmowane przez państwo w stosunkach zewnętrznych, które charakteryzują się spójnością, warunkowane zaś są zarówno sytuacją wewnętrzną i zewnętrzną. Edward Haliżak zwraca uwagę, że u progu XXI w. Japonia stoi przed istotnym dylematem. Wyboru między rolą „,normalnego państwa” a rolą „mocarstwa cywilnego” oraz wybory między Wschodem a Zachodem. Rola „normalnego państwa” wiązałaby się przede wszystkim ze zwiększeniem znaczenia sił zbrojnych oraz większą aktywnością Japonii w regionie oraz w wymiarze globalnym. Wybór zaś między Wschodem a Zachodem polegałby w dużej mierze na określeniu, na ile Japonia chce i jest gotowa pełnić samodzielną rolę w Azji Wschodniej? Czy raczej chce 
pozostać państwem o korzeniach azjatyckich, ale reprezentującym interesy świata Zachodu, a przede wszystkim Stanów Zjednoczonych w regionie? ${ }^{1}$

Według Thomasa Bergera Japonia z racji swej potęgi gospodarczej i technologicznej jest predysponowana do odgrywania roli mocarstwa zarówno ekonomicznego jak i militarnego. W swej polityce bezpieczeństwa, niemniej jednak była wierna kulturze antymilitarystycznej. ${ }^{2} \mathrm{~W}$ związku z tym nasuwają się kolejne pytania: czy rolę Japonii ogranicza jej kultura strategiczna? Jeżeli tak, to czy Japonia będzie dążyła do jej zmiany? Wreszcie na ile zmiana ta jest realna? A zatem, jak pisał Th. Berger czy faktycznie jest tak, że kultury zachowują pewną autonomię i niekoniecznie muszą odzwierciedlać konkretną „obiektywną” rzeczywistość? ${ }^{3}$ Czy raczej „obiektywna” rzeczywistość wymusza zmianę również w sferze kultury?

Punktem wyjścia do analizy jest przyjęte 17 września 2015 roku przez izbę wyższą japońskiego parlamentu, przy sprzeciwie społecznym, prawo umożliwiające działania w ramach tzw. wspólnej obrony poza granicami Japonii oraz teza według której współczesna kultura strategiczna Japonii zmienia się mimo wewnętrznego instytucjonalnego antymilitaryzmu.

\section{KULTURA STRATEGICZNA}

Wprowadzenie do słownika stosunków międzynarodowych pojęcia kultury strategicznej przypisuje się Jackowi Snyderowi, który zastanawiając się nad radziecką doktryną nuklearną zaproponował teorię kultury strategicznej. Według niego kultura strategiczna jest formułowana przez elity i jest dostosowana do konkretnych problemów bezpieczeństwa i wojskowości, jest również manifestacją opinii publicznej, przejawiającą się w specyficznym sposobie myślenia strategicznego. Zatem, twierdził, że zbiór sądów ogólnych, postaw i wzorców zachowań związanych ze strategią nuklearną osiągnął stan względnej trwałości, który jest bardziej charakterystyczny dla kultury niż czystej polityki. ${ }^{4}$ Analizy kultury strategicznej oraz tego jaki wpływ ma kultura na kształtowanie strategii podjął się również Colin Gray. Uważa, że kultura strategiczna to swoisty sposób myślenia s. 164.

1 E. Haliżak, Stosunki międzynarodowe w regionie Azji i Pacyfiku, Scholar, Warszawa 1999,

2 J. S. Lantis, D. Howlett, Kultura strategiczna (w:) Strategia we wspótczesnym świecie. Wprowadzenie do studiów strategicznych, J. Baylis, J. Wirtz, C. S. Gray, E. Cohen (red.), Wydawnictwo UJ, Kraków 2009, s. 95.

3 Ibidem.

4 J. L. Snyder, The Soviet Strategic Culture: Implications for Limited Nuclear Operations, A project AIR FORCE report prepared for $\mathrm{y}=$ the United States Air Force, RAND, September 1977, s. 8-9, https://www.rand.org/content/dam/rand/pubs/reports/2005/R2154.pdf (data dostępu: luty 2016), zob. J. S. Lantis, D. Howlett, Kultura strategiczna (w:) Strategia we współczesnym świecie. Wprowadzenie do studiów strategicznych, J. Baylis, J. Wirtz, C. S. Gray, E. Cohen (red.), Wydawnictwo UJ, Kraków 2009. 
o sile i postępowania, wynikający z narodowego doświadczenia historycznego. ${ }^{5}$ Stwierdził też, że czasami trudno w jednoznaczny sposób udowodnić wpływ kultury na strategię, nie można jednak również jej kategorycznie wykluczyć.

Należy podkreślić, że przy analizie zachowań państw, zaczęto odwoływać się do modeli antropologicznych znacznie wcześniej, bo w latach czterdziestych i pięćdziesiątych XX w. Pojawił się wówczas nurt studiów nad charakterem narodowym. W kontekście Japonii należy zwrócić uwagę na pracę Ruth Benedict zatytułowaną „Chryzantema i miecz: wzory kultury japońskiej”. Książka ta była efektem badań, których celem było zrozumienie kultury wroga - Japonii. Badania R. Benedict doprowadziły ją do pewnej konkluzji. W kulturze japońskiej można wyróżnić dwa nurty: militarystyczny i agresywny - miecz oraz pokojowy i otwarty - chryzantema. ${ }^{6}$ Tym samym jak podkreśla Rafał Wiśniewski zastosowana tam analiza kulturowa $\mathrm{w}$ rozumieniu polityki i strategii przeciwnika upoważnia do stwierdzenia, że praca R. Benedict była prekursorem w badaniu kultury strategicznej Japonii. $^{7}$

Kulturę strategiczną można definiować w sposób szeroki, jako odrębny i trwały zbiór przekonań, wartości i zachowań dotyczących zagrożeń i użycia siły, warunkowanych położeniem geopolitycznym, historią, kulturą polityczną. Jak również w sposób zawężający, jako odrębny zestaw przekonań uznawanych przez dominującą elitę polityczną i tym samym wpływający na praktykę polityczną związaną z bezpieczeństwem militarnym. W tym drugim ujęciu nasuwa się pytanie czy możemy mówić o jednej, czy o wielu kulturach strategicznych, które ze sobą rywalizują? Jak ma to miejsce w debacie politycznej, w trakcie której widoczna jest rywalizacja między różnymi elitami politycznymi, które prezentują odmienne podejście do bezpieczeństwa i strategii. ${ }^{8}$

\section{CIĄGŁOŚĆ I ZMIANA KULTURY STRATEGICZNEJ JAPONII}

Andrew Oros wyróżnił kilka typów kultury strategicznej Japonii. ${ }^{9}$ Kryterium różnicującym jest czas, jak również czynniki wewnętrzne i zewnętrzne, w tym położenie geopolityczne oraz brak zasobów naturalnych. Zgodnie z tą typologią początkowo kulturę strategiczną Japonii można określić jako kulturę izolacjonizmu i antymilitarną. Decyzja o izolacji Japonii w dużej mierze wiązała się z obawami, by Japonia nie podzieliła losu swoich azjatyckich sąsiadów i nie stała się kolejną zachodnią posiadłością kolonialną, czemu sprzyjało rozbicie

5 C. Gray, Strategy and Politics, Routledge, New York 2016, s. 96-97.

6 Zob: R. Benedict, Chryzantema i miecz: wzory kultury japońskiej, PIW, Warszawa 2003.

7 R. Wiśniewski, Kultura strategiczna, czyli o kulturowych uwarunkowaniach polityki zagranicznej i bezpieczeństwa, „Przegląd Strategiczny” 2012, nr 1, s. 166.

8 A. L. Oros, Japan's Stretegic Culture: Security Identity in a Fourth Modern Incarnation? "Contemporary Security Policy" 2014, vol. 35, N0.2, s. 228.

9 Ibidem, s. 231-232. 
wewnętrzne i bark silnej władzy. Działaniom, których celem było zjednoczenie, towarzyszyła zatem decyzja o samoizolacji, która trwała 200 lat, do czasu gdy początkowo Stany Zjednoczone w 1854 r., a w następnych latach Brytyjczycy i Francuzi wymusili na Japonii otwarcie. Otwarciu sprzyjała też sytuacja wewnętrza, słabość gospodarki, bunty społeczne, oraz restauracja władzy cesarskiej zapoczątkowana przez cesarza Mutsuhito. Zapoczątkowało to modernizację państwa w wielu wymiarach również militarnym, co uwidoczniło również imperialne aspiracje Japonii. W konsekwencji możemy mówić o zmianie kultury strategicznej Japonii na kulturę otwartą, ale również militarystyczną. Jej przejawem była ekspansja terytorialna, wygrana wojna z Chinami, w wyniku której Japonia weszła w posiadanie Tajwanu i Peskadorów (1895 r.). Kolejne zwycięstwo odniosła Japonia w wojnie z Rosją (1904-1905), tym samym zdobyła rosyjskie koncesje we wschodniej Mandżurii, przejęła Port Artur, południową cześć Sachalinu oraz mogła kontynuować dalszą ekspansję w Azji Wschodniej. W 1910 roku zaanektowała Koreę, a w następnych latach poszerzała stopniowo swoje wpływy. W 1942 roku poddanie się sił amerykańskich na Filipinach, skutkował tym, że do końca wojny na Pacyfiku znaczna część Azji Wschodniej znalazła się pod zwierzchnictwem jednego państwa - Japonii. To w tym okresie Japonia mówiła o konieczności stworzenia Strefy Wspólnego Dobrobytu Wielkiej Azji Wschodniej. Pomysł miał w dużej mierze charakter propagandowy - Azja dla Azjatów, służył również umocnieniu pozycji Japonii w regionie przez podporządkowanie terenów bogatych $\mathrm{w}$ surowce naturalne. Cechą znamienną było również to, że pomimo modernizacji i zmian kultura Japonii nadal silnie była powiązana z przeszłością i wartościami samurajów.

Klęska w 1945 roku skutkowała przesunięciem w kulturze strategicznej. Przy dalszej otwartości (szczególnie w sferze kultury) wybrano, może nie do końca woluntarystycznie, antymilitaryzm. W wymiarze wewnętrznym umacniano postawę antymilitarną, w zewnętrznym gwarantem bezpieczeństwa Japonii był, nieoparty na zasadzie wzajemności, sojusz wojskowy z USA. Jednocześnie Japonia stała się zwolenniczką wszechstronnego podejścia do bezpieczeństwa, uwzględniając potrzebę bezpieczeństwa dostępu do surowców i rynków, chociaż bez konieczności podejmowania działań militarnych. Równocześnie prowadzona została bardzo skuteczna polityka wizerunkowa. Japonia miała być postrzegana jako państwo miłujące pokój, zaangażowane w międzynarodową pomoc humanitarną. Polityka ta okazała się na tyle skuteczna, że utrwaliło się przekonanie o nieposiadaniu sił zbrojnych przez to państwo. W rzeczywistości Japonia dysponuje Siłami Samoobrony, które jednak w okresie zimnej wojny, były postrzegane jako niezdolne do podejmowania skutecznych działań, które mogłyby zagwarantować bezpieczeństwo własnym obywatelom. W dobitny sposób obrazują to wczesne filmy o Godzili. Sytuacja uległa zmianie w latach 90. XX wieku. Siły Samoobrony zaczęly stopniowo zmieniać swój wizerunek, co prawda nadal nie mogły tego robić na polu walki, ze względu na ograniczenia konstytucyjne, ale bardzo aktywnie zaangażowały się w niesienie pomocy humanitarnej, jak również 
udział w misjach pokojowych. To międzynarodowe zaangażowanie było również konsekwencją oczekiwań ze strony środowiska międzynarodowego, bowiem państwo, które posiada wysoką pozycję ekonomiczną powinno bardziej angażować się w pomoc międzynarodową w różnych wymiarach.

Obecnie pozycja militarna Japonii jest znacząca. Według SIPRI Japonia w 2014 r. posiadała 4 pozycję na świecie pod względem wydatków militarnych, a zgodnie $\mathrm{z}$ rankingiem przygotowanym przez The Military Balnace 8 pozycje w 2015 r. ${ }^{10} \mathrm{~W}$ rankingu Global Firepower Japonia w 2016 roku posiada 7 pozycję militarną na 126 państw. ${ }^{11}$ Jednocześnie celem zmiękczenia wizerunku militarnego w Japonii, szczególnie w wymiarze wewnętrznym, chętnie wykorzystuje się mangę, czy kulturę cutness (kawaii). Japonia bardzo skutecznie też buduje swój wizerunek państwa przyjaznego. W 2015 r. osiągnęła wysoką, ósmą pozycję w światowym Rankingu Soft Power. ${ }^{12}$ Ma najwyższą pozycje wśród państw azjatyckich - Republika Korei pozycja 20, Singapur - 21, Chiny pozycja 30. To co Japonię wyróżnia to nowoczesna technologia, precyzja, wysmakowana kultura, dobra luksusowe. Jest nadal głównym światowym darczyńcą oraz źródłem kapitału. W 2014/2015 w Country Brand Index Japonia uplasowała się na pierwszej pozycji. ${ }^{13} \mathrm{~W}$ sondażu przygotowanym przez Pew Research Center w 2015 r., $71 \%$ respondentów pozytywnie postrzegało Japonię w regionie Azji i Pacyfiku, również obecny premier Japonii Shinzo Abe jest pozytywnie postrzegany przez 43\% respondentów, najlepiej w Malezji, Filipinach, Wietnamie, Australii. Znacznie gorzej w Republice Korei czy w Chinach, co warunkowane jest zaszłościami historycznymi oraz bieżącą polityką. ${ }^{14}$ Ważnym czynnikiem kształtującym pozytywny wizerunek Japonii, poza angażowaniem się w misje pokojowe, jest również udzielanie pomocy w ramach Oficjalnej Pomocy Rozwojowej. W 2015 r. Japonia zajęła tu 4 miejsce na świecie po USA, Wielkiej Brytanii i Niemczech. ${ }^{15}$

Tym działaniom wizerunkowym towarzyszą kroki, których celem jest realne wzmocnienie politycznej i militarnej pozycji Japonii, jednak przy zachowaniu pokojowej retoryki. W 2013 r. przyjęto pierwszą Narodową Strategię Bezpieczeństwa, w której wraz z Wytycznymi Programu Obrony Narodowej (National

${ }^{10}$ Stockholm International Peace Research Institute, http://www.sipri.org/media/pressreleases/2014/Milex_April_2014The Military Balance, https:/www.iiss.org/en/publications/military\%20balance/issues/the-military-balance-2016-d6c9 (data dostępu: kwiecień 2016).

${ }^{11} \mathrm{http} / / /$ www.globalfirepower.com/country-military-strength-detail.asp?country_id=japan (data dostępu: kwiecień 2016).

${ }^{12}$ The Soft Power 30, http://softpower30.portland-communications.com/ranking (data dostępu: marzec 2016).

${ }^{13}$ Country Brand Index 2014/2015, http://www.futurebrand.com/cbi/2014 (data dostępu: marzec 2016).

${ }^{14}$ How Asia-Pacific Publics See Each Other and Their National Leaders, http://www.pewglobal.org/2015/09/02/how-asia-pacific-publics-see-each-other-and-their-national-leaders/ (data dostępu: kwiecień 2016).

${ }^{15} \mathrm{http}$ //www.oecd.org/newsroom/aid-to-developing-countries-rebounds-in-2013-to-reach-an-all-time-high.htm (data dotępu: kwiecień 2016). 
Defence Program Guidelines 2010 r.), została przedstawiona idea proaktywnego udziału w utrzymaniu pokoju, oparta na zasadzie międzynarodowej kooperacji. Wiąże się ona z promowaną przez premiera Shinzo Abe ideą proaktywnego pacyfizmu. ${ }^{16}$ Świadczy to o podjętej próbie zmiany roli Japonii w regionie i świecie, z postawy pasywnej na bardziej aktywną. Czy będzie to pociągało za sobą zmianę jej kultury strategicznej? Jeżeli tak to $\mathrm{w}$ jakim kierunku? Jak można zinterpretować wywiad w Foreign Affairs z premierem Szinzo Abe z 2013 zatytułowany „Japan is Back”, czy wystąpienie o tym samym tytule w Centrum Studiów Strategicznych i Międzynarodowych (Center for Strategic and International Studies CSIS) w dniu 24 lutego 2013 r.? ${ }^{17}$

Jak zwraca uwagę Kamiya koncepcja proaktywnego pacyfizmu, nie jest zupełnie nowa i była dyskutowana w Japonii od pewnego czasu. Podkreślił, że w postwojennej Japonii można wyróżnić dwa rodzaje pasywności. Pierwsza charakteryzuje się brakiem chęci do działań proaktywnych w celu zachowania pokoju. Druga to brak chęci do wykorzystania siły militarnej dla zachowania pokoju. Tym samym stwierdził, że japoński pacyfizm na poziomie wewnętrznym charakteryzuje się brakiem intencji do działań w imię pokoju. Jednocześnie stawia retoryczne pytanie czy bez siły militarnej w ogóle można zagwarantować pokój, szczególnie uwzględniając obecną sytuację międzynarodową? ${ }^{18}$

Zatem można stwierdzić, że obecnie kultura strategiczna Japonii to rodzaj proaktywnego pacyfizmu. W dużej mierze ma on polegać na usunięciu ograniczeń w polityce obronnej Japonii. Uwypukla się, że silna pozycja ekonomiczna i militarna Japonii będzie też gwarancją na zachowanie pokoju i stabilność w regionie Azji i Pacyfiku. Niektórzy porównują działania premiera Shinzo Abe do działań w podejmowanych na przełomie XIX i XX w., określając je jako restauracja Meiji 2.0. ${ }^{19}$ Ta zmiana w kulturze strategicznej ma też swoje uwarunkowania obiektywne, jak chociażby położenie Japonii czy brak surowców, bez których trudno sobie wyobrazić dalszy rozwój państwa. ${ }^{20}$

${ }^{16}$ Kamiya Matake, A Nation of Proactive Pacifism - National Strategy for Twenty-first-Century Japan, "Discuss Japan - Japan Foreign Policy Forum" 2014, nr 18, http://www.japanpolicyforum.jp/pdf/2014/vol18/DJweb_18_dip_1.pdf (data dostępu: marzec 2016).

17 "Japan is Back", Policy Speech by Prime Minister Shinzo Abe at the Center for Strategic and International Studies (CSIS) http://www.mofa.go.jp/announce/pm/abe/us_20130222en.html, (data dostępu: marzec 2016), Japan is Back. A Conversation with Shinzo Abe, "Foreign Affairs" 2013, July/August.

${ }^{18}$ Kamiya Matake, A Nation of Proactive..., s. 2.

19 J. A. Bosco, Japan: From "Proactive Pacifism" to "Proactive Diplomacy", "The Diplomat" 2015, 15 Nov, http://thediplomat.com/2015/02/japan-from-proactive-pacifism-to-proactive-diplomacy/ (data dostępu: kwiecień 2016).

${ }^{20}$ T. French, Narrative oh Humiliation: China and Japanese Strategic Culture, "Center for Security Studies" 2012, International Relations and Security Network, https://www.files.ethz.ch/ isn/188767/ISN_141042_en.pdf (data dostępu: kwiecień 2016). 


\section{UWARUNKOWANIA ZMIAN W KULTURZE STRATEGICZNEJ}

Jakie mogą być główne przyczyny zmiany w kulturze strategicznej państwa? Kultura jest zjawiskiem dynamicznym, niemniej jednak zmiany, w kulturze zachodzą stosunkowo powoli. Podobnie zmiany w kulturze strategicznej wymagają czasu, chyba że zaistnieją okoliczności, które będą jej przyśpieszą. Wg Jeffreya Lantisa można wskazać na dwie sytuacje, które stawiają kulturę strategiczną przed dylematem i prowadzą do zmian w polityce zagranicznej. Może to być, po pierwsze, wstrząs pochodzący z zewnątrz, który podważa podstawy dotychczasowych przekonań i kompromituje dawne przekazy historyczne. Jak zwraca uwage J. Lantis towarzyszą temu wielkie napięcia psychiczne i potrzeba społecznej internalizacji wprowadzonych przez nie zmian. Po drugie, gdy podstawowe założenia koncepcji strategicznych popadają w konflikt miedzy sobą. Jak wówczas gdy państwo, które jest związane zasadami dotyczącymi niechęci użycia siły, staje wobec potencjalnych i realnych zagrożeń. Wówczas ma moralne prawo i obowiązek podejmować działania, które wykraczają poza przyjętą strategię. ${ }^{21}$ Hans Morgenthau podkreśla, że na zmianę kultury strategicznej może wpływać chęć uzyskania hegemonicznej pozycji, co staje się przesłanką do rywalizacji realizm ofensywny. ${ }^{22}$ Uczestniczą w niej państwa, które są w stanie rywalizować $\mathrm{z}$ aktualnym hegemonem, $\mathrm{z}$ aktualnym mocarstwem. W regionie Azji i Pacyfiku pozycję mocarstwową posiadają Stany Zjednoczone, które mają jednak poważnego konkurenta - Chiny. Można postawić siebie pytanie, na ile stabilny jest sojusz Waszyngton-Tokio? Czy Japonia nie będzie dążyła do przejęcia pozycji USA w regionie, jak sugerowali jeszcze w latach 90 . XX w. G. Freidman i M. LeBard ${ }^{23}$ Czy Japonia nie będzie chciała rywalizować o pozycję regionalnego mocarstwa z Chinami? Aspiracje mocarstwowe Japonii potwierdzają obecnie bardzo dobitnie wypowiedzi Shinzo Abe, według którego należy przywrócić Japonii należne jej miejsce. Przypisuje on też Japonii wyjątkową rolę i sugeruje odtworzenie pod jej przywództwem Azjatyckiej Strefy Dobrobytu. ${ }^{24} \mathrm{Z}$ kolei realizm defensywny zakłada, że państwo będzie dążyło do rozbudowy swojego potencjału militarnego, aby zagwarantować sobie bezpieczeństwo w odpowiedzi na pojawiające się zagrożenia zewnętrzne, takie jak w przypadku Japonii zagrożenia ze strony Korei Północnej (program nuklearny), czy Chin (np. rywalizacja na Morzu Wschodniochińskim).

Na kształt kultury strategicznej, jak pisał J. Snyder, wpływają zatem elity. Jest ona odpowiedzią na konkretne problemy bezpieczeństwa i wojskowości. Jest manifestacją opinii publicznej, przejawiającą się specyficznym sposobie

${ }^{21}$ J. S. Lantis, D. Howlett, Kultura strategiczna..., s. 101, zob. J. S. Lantis, Strategic culture and National Security Policy, "International Studies Review" 2002, vol. 4, no. 3.

${ }^{22}$ Zob. H.J. Morgenthau, Polityka miedzy narodami. Walka o potęgę i pokój, Difin SA, Warszawa 2010.

${ }^{23}$ G. Freidman, M. LeBard, The Coming War with Japan, St. Martin's Press 1991.

24 "Japan is Back", Policy Speech by Prime Minister Shinzo Abe... op. cit. 
myślenia. ${ }^{25}$ Tym samym pewne wydarzenia, zachowania innych państw, czy podmiotów niepaństwowych, mogą skutkować dążeniem do zmiany kultury strategicznej. Te uwarunkowania wpływał na zmianę kultury strategicznej Japonii w przeszłości (reformy Meiji, porażka w wojnie na Pacyfiku) oraz są widoczne współcześnie. Zatem po pierwsze obserwowana jest zmiana percepcji zagrożeń, która skutkowała zaangażowaniem się w działania na Bliskim Wschodzie, w tym wojnę z terroryzmem. Ważnym momentem był kryzys w Algierii w styczniu 2013 r. wywołany atakiem na pola naftowe Ajn Amenas, gdzie zakładnikami i ofiarami byli również obywatele Japonii. Zaangażowanie Japonii w regionie było widoczne już wcześniej. Zaraz po upadku muru berlińskiego, Saddam Hussein zaatakował Kuwejt, co stało się przyczyną pierwszej wojny w Zatoce Perskiej. Wówczas jednak Japonia ograniczyła się do dyplomacji czekowej. Nie bez znaczenia jest wzrost pozycji Chin i ich polityka w regionie. Przede wszystkim zaś spory terytorialne na morzach, w które zaangażowane są Chiny i w których też stroną jest Japonia. Chodzi głównie o Morze Wschodniochińskie. Zaś największe kontrowersje towarzyszą Wyłącznym Strefom Ekonomicznym wytyczanym na spornych obszarach, chińskiej strategii pierwszego łańcuch wysp, czy wyznaczenie chińskiej Strefy Identyfikacji Obrony Powietrznej na Morzu Wschodniochińskim.

Na zmianę kultury strategicznej może mieć wpływ sytuacja na Półwyspie Koreańskim, a szczególnie realizowany program nuklearny i rakietowy KRLD. Państwo to prowadzi testy z pociskami balistycznymi od lat 90 . XX w. Zaś eskalacja nastąpiła w 2006 r. Skutkowało koniecznością redefinicji zagrożeń dla bezpieczeństwa narodowego Japonii. Kolejną kwestią są nierozwiązane spory terytorialne z Rosją i Koreą Południową. Wreszcie oczekiwania ze strony sojuszników Japonii, a szczególnie USA, czy oczekiwania ze strony społeczeństwa Japonii. T. Berger zwraca właśnie uwagę na uwarunkowania wewnętrzne, które również mogą być impulsem do remilitaryzacji. Są to: silny nacjonalizm etnocentryczny, specyficzne połączenie lojalności grupowej przy jednoczesnym braku centralizacji w podejmowaniu decyzji oraz relatywny bark poczucia winy za krzywdy wojenne. ${ }^{26}$ Należy też podkreślić, że Japonia stoi przed dylematem, jak pogodzić instytucjonalny antymilitaryzm $\mathrm{z}$ istniejącymi zagrożeniami? Z punktu widzenia Japonii wydaje się, że odpowiedź jest jedna. Istnieje moralne prawo do zmiany strategii, aby sprostać wyzwaniom współczesności.

Tym samym obserwujemy odchodzenie od doktryny Yoshidy, która od kilkudziesięciu lat określała politykę Japonii. Doktryna ta opierała się na całkowitej reorientacji na współpracę z USA i innymi państwami Zachodu. Ograniczała rolę Japonii w stosunkach międzynarodowych do sfery stosunków ekonomicznych. Było to zaś możliwe dzięki przyjęciu gwarancji bezpieczeństwa ze strony USA,

${ }^{25}$ Zob. J. L. Snyder, op. cit.

${ }^{26}$ T. Berger, From Sword to Chrysanthemum: Japan's Culture of Anti-militarism, "International Security" 1993, vol. 17. No. 4, s. 124. 
w zamian za udostępnienie baz wojskowych. Próby rewizji tej doktryny były podejmowane kilkakrotnie, ale bez większego sukcesu. Shinzo Abe, gdy pierwszy raz sprawował urząd premiera w latach 2006-2007, przyczynił się przyjęcia kilku regulacji, które umożliwiły Japonii większą współpracę w sprawach bezpieczeństwa z sojusznikami. Proponował też utworzenie Rady Bezpieczeństwa Narodowego, przyczynił się do zniesienia ograniczeń dotyczących wysyłania oddziałów wojskowych poza granice Japonii. Jego następca z Partii Demokratycznej (DPJ) zamroził dotychczasowe zmiany. Premier Hatoyama był bowiem zwolennikiem azjatyckiej, a nie zachodniej tożsamości politycznej Japonii. Co przejawiało się w reorientacji na stosunki z azjatyckimi sąsiadami: Chinami i Republiką Korei. W tamtym czasie stosunki z USA były dość napięte, w dużej mierze ze względu na propozycję przeniesienia amerykańskich baz wojskowych z Okinawy. Po dramatycznych wydarzenia tsunami z 2011 r., które spowodowały kryzys nuklearny w Japonii następca Hatoyamy Naoto Kan podał się do dymisji, zaś kolejny premier Yoshihko Noda preferował bardziej konserwatywną polityką, zorientowaną na sojusz z USA. Przejawem była zgoda na zakup F-35 - myśliwca wielozadaniowego, tym samym doszło do zliberalizowania przepisów dotyczących importu uzbrojenia. Premier Noda brał też udział w negocjacjach w sprawie Transpacyficznego Partnerstwa (TPP), wykluczającego Chiny. Za jego rządów doszło też w 2012 r. do nacjonalizacji trzech wysp z archipelagu Senkaku/Diaoyu, do których prawa zgłaszają Chiny i Tajwan. Skutkowało to zaostrzeniem stosunków na linii Pekin-Tokio. Obecnie premier Shinzo Abe stawia nadal na rozwijanie stosunków z ChRL, Republiką Korei, państwami ASEAN, ale też mówi o konieczności umacnianiem pozycji w regionie Azji i Pacyfiku. Ponadto podkreśla konieczność dalszego umacniania sojuszu z USA i zwiększania możliwości obronnych Japonii. To wszystko ma prowadzić do przywrócenia Japonii należnego jej miejsca. Polityka prowadzona przez obecnego premiera ma na celu zniesienie powojennych restrykcji na handel bronią, jak również wykorzystywania Sił Samoobrony poza granicami Japonii. W ocenie ekspertów zniesienie zakazu eksportu broni może mieć pozytywny wpływ na rozwoju przemysłu zbrojeniowego. ${ }^{27}$ Tym samym przyczyni się dalszego zwiększania pozycji militarnej Japonii.

Zatem można stwierdzić, że premierzy Japonii odgrywają istotną rolę w kształtowaniu celów polityki zagranicznej i decydują, jak dalece i w jakim kierunku należy ją przekształcić w obliczu nowych wyzwań. Liderzy i elity polityczne redefiniują granice tego co możliwe, zarówno opisowo, jak i postulatywnie. ${ }^{28}$ Czyli kultura strategiczna to ,rzeczywistość negocjowana”. ${ }^{29}$ Zatem w zależności

${ }^{27}$ Zob. M. Auslin, Japan's New Realism. Abe Gets Tough, "Foreign Affairs" 2016, March/ April.

${ }^{28}$ Zob. C. Cruz, Identity and Persuasion: How Nations Remember their Past and Make the Futures, "World Politics" 2000, 52/3, J. S. Lantis, D. Howlett, Kultura strategiczna..., s. 99.

${ }^{29}$ T. U. Berger, Cultures of Antimilitarism: National Security in Germany and Japan, MD, Johns Hopkins University Press, Baltimore 1998, cyt. za: J. S. Lantis, D. Howlett, Kultura strategiczna..., s. 99. 
od obiektywnych uwarunkowań oraz oczekiwań ze strony społeczeństwa, decydenci są skłonni wykraczać poza pewne granice, lub też je zmieniać w zależności od potrzeb.

\section{GWARANCJA ZACHOWANIA STATUS QUO W KULTURZE STRATEGICZNEJ I TENDENCJE DO ZMIANY}

Zmianę kultury strategicznej Japonii nadal w znacznym stopniu ogranicza konstytucja. W artykule 9 zostało zapisane: „Naród japoński, dążąc szczerze do międzynarodowego pokoju opartego na sprawiedliwości i porządku, wyrzeka się na zawsze wojny jako suwerennego prawa narodu, jak również użycia lub groźby użycia siły jako środka rozwiązywania sporów międzynarodowych. Ponadto zapisano, że dla osiągnięcia powyższego celu nigdy nie będą utrzymywane siły lądowe, morskie i powietrzne ani inne środki mogące służyć wojnie. Aby tym samym podkreślić, że nie uznaje się prawa do prowadzenia wojny". ${ }^{30}$ Zatem zmiana kultury strategicznej wymaga też zmiany konstytucji. Te zaś są stopniowo podejmowane i thumaczone głównie faktem, że obecny dokument jest anachroniczny i nie pasuje do współczesnej sytuacji. Istotna jest też zmiana artykułu 96 konstytucji, który co prawda przewiduje możliwość dokonania zmian w konstytucji, ale pod warunkiem uzyskania $2 / 3$ głosów ogólnej liczby członków obu izb parlamentu, a następnie zatwierdzenie zmian przez większość ogólnej liczby głosów społecznych, oddanych w referendum lub w trakcie wyborów powszechnych. ${ }^{31}$ Do tej pory trudno było uzyskać wymaganą większość $2 / 3$, jak również instytucja referendum nie miała zastosowania w Japonii. Aby referendum zakończyło się sukcesem, należy zatem przekonać społeczeństwo Japonii. W tym monecie zaś przekonanie opinii publicznej do wyrażania zgody na zmianę, wydaje się mało prawdopodobne. Według badania opinii publicznej przeprowadzonego przez Kyodo News, w 2015 r. 60\% Japończyków była przeciwna zmianom konstytucji, za opowiadało się $32 \%$. Należy jednak podkreślić, że z roku na rok przyzwolenie na zmiany w konstytucji widocznie wzrasta. ${ }^{32} \mathrm{~W}$ kwietniu $2016 \mathrm{r}$. sondaże wskazywały, że już 37\% Japończyków popiera zmiany art. 9 konstytucji i $50.3 \%$ jest im przeciwna. ${ }^{33}$

Celem wprowadzania zmian w Konstytucji Japonii Shinzo Abe jeszcze w 2007 r. powołał Doradczy Panel ds. Rekonstrukcji Podstaw Prawnych dla Bezpieczeństwa (Advisory Panel on Reconstruction of Legal Basis for Security).

${ }^{30}$ Konstytucja Japonii. Biblioteka Sejmowa. Konstytucje świata, thumaczenie z języka japońskiego Teruji Suzuki, Warszawa 2014

${ }^{31}$ Ibidem.

${ }^{32}$ The Japan Times News, http://www.japantimes.co.jp/news/2015/07/22/national/politics-diplomacy/60-say-constitution-changed-kyodo-poll/\#.Vx49BvmLRD8 (data dostępu: kwiecień 2016).

${ }^{33}$ The surrender of Japan's Peace Constitution, http://opinion.inquirer.net/94224/the-surrender-of-japans-peace-constitution (data dostępu: kwiecień 2016). 
Po odejściu Abe, raport przygotowany przez Panel nie spotkał się z życzliwym przyjęciem. Jednak jego powrót do władzy w 2012 r. ponownie uruchomił prace i działania Panelu Doradczego. Jego prace koncentrowały się głównie na próbie udzielenia odpowiedzi na pytanie, czy występuje deficyt bezpieczeństwa w systemie prawnym Japonii, oraz zaproponowanie sposobów naprawy tej sytuacji. Jak zauważa Kitaoka Shinichi z International University of Japan, dynamika sytuacji międzynarodowej wymaga działań $\mathrm{w}$ tym względzie. ${ }^{34}$ Wskazał tym samym na kilka kwestii, które wiążą się z bezpieczeństwem i wymagają doprecyzowania. Jak podkreśla zgodnie z prawem premier Japonii ma prawo zmobilizować Siły Samoobronny, jeżeli państwu zagraża atak zbrojny, definiowany jako zorganizowana i zaplanowana inwazja przez inne państwo. Według niego jednak ta definicja nie jest precyzyjna bowiem jak definiować konflikty o niskiej intensywności. Jako przykład podał działania Rosji na Ukrainie. Kolejną kwestią jest prawo do wspólnej obrony. Wszystkie państwa mają prawo do obrony w sytuacji ataku, co zresztą nie budzi zastrzeżeń. Jednak państwom średnim i małym trudno to prawo zrealizować w sytuacji, gdy zostaną zaatakowane przez mocarstwo. Dlatego potrzebne jest zagwarantowania prawa do wspólnej obrony. Tym samym wskazuje na kilka kryteriów, które uzasadniają korzystanie z prawa do wspólnej obrony. Po pierwsze atak bez uprzedzenia na państwo sojusznika Japonii. Po drugie pomoc państwu zaatakowanemu, które zwróci się z prośbą o taką pomoc. Po trzecie prawdopodobieństwo wystąpienia negatywnych konsekwencji dla bezpieczeństwa Japonii, jeżeli nie podejmie się takich działań. Po czwarte zaakceptowanie takich działań przez parlament. Po piąte ocena takich działań przez premiera uwzględniając bilans zysków i strat. Po szóste uzyskanie zgody od państw trzecich w sytuacji gdy potrzeba zrealizowania prawa do wspólnej obrony wiąże się z koniecznością przemieszczenia się przez ich terytoria. ${ }^{35}$ Według autora najważniejsze są kryteria trzecie i piąte, wówczas rząd Japonii musi podejmować decyzje zarówno rozważnie, jak i szybko. Tym samy takie sytuacje stają się prawdziwym testem dla premiera, na którym ciąży faktyczna odpowiedzialność za podejmowanie decyzji związanych z bezpieczeństwem Japonii. ${ }^{36}$ Wspomniany art. 9 konstytucji, na przestrzeni ulegał pewnym reinterpretacjom, chociaż ich źródłem nie był Sąd Najwyższy, a Gabinet Biura Legislacyjnego (Cabinet Legislation Bureau), infiltrowany przez wpływowych urzędników ministerialnych, samych ministrów czy partię rządzącą. Gabinet wydał kilka ważnych interpretacji konstytucji, których celem było wspieranie aktualnej polityki partii rządzącej. Istotnym obszarem działań interpretacyjnych jest kwestia wspólnej obrony, a szczególnie określenia sytuacji kiedy Siły Samoobrony mogą uczestniczyć w działaniach militarnych

${ }^{34}$ Kitaoka Shinichi, Do not forget about national security by clinging to the constitution - Significance of a report submitted by the Advisory Panel on Reconstruction of Legal Basis for Security, "Discuss Japan, Japan Foreign Policy Forum" 2014, no. 23, Nov. 19, http://www.japanpolicyforum.jp/archives/politics/pt20141119222454.html (data dostępu: kwiecień 2016).

${ }^{35}$ Ibidem.

${ }^{36}$ Ibidem. 
wspólnie z innymi państwami, w innych sytuacjach niż bezpośrednia obrona terytorium Japonii. Tym samym Japonia starała się od lat wkomponowywać w system bezpieczeństwa światowego. Jeszcze w trakcie wojny w Zatoce Perskiej działania Japonii ograniczały się do pomocy finansowej (dyplomacja czekowa). Później przyjęto szereg ustaw, których celem była większa aktywność Japonii w sferze bezpieczeństwa. W 1992 roku przyjęto ustawę dotyczącą współpracy w ramach operacji pokojowych ONZ. W praktyce umożliwiła ona wysyłanie żołnierzy japońskich (nie więcej jednak niż 2 tyś.) w różne regiony świata w ramach działań antykryzysowych, humanitarnych, wsparcia logistycznego (Kambodża 1991 r., Angola 1993 r., Mozambik, Salwador, Zair i Kenia 1994 r., Wzgórza Golan 1995, granica izraelska-syryjska 1996, Jugosławia). W $2001 \mathrm{r}$. został przyjęty pakiet ustaw o specjalnych środkach zwalczania terroryzmu. W 2004 r. przyjęto ustawę umożliwiającą wysłanie żołnierzy do Iraku, celem były wspólne działania z USA w odbudowie Iraku. Była to przełomowa data, bowiem wówczas pierwszy raz wysłano Siły Samoobrony poza granice państwa, w innych celach niż dotychczasowe działania podejmowane w misjach pokojowych ONZ. Japonia aktywnie włączyła się również w zwalczanie piractwa morskiego. Na mocy ustawy z 2009 r., rząd premiera Aso Taro wysłał np. okręty do wybrzeży Somalii. W 2015 roku została przyjęta (weszła w życie w lutym 2016 r) reinterpretacja „,wspólnej obrony”, którą zaczęto tłumaczyć jako prawo do przyjścia sojusznikowi z pomocą i wykorzystanie swoich sił. Wymienia się też konkretne przypadki w jakich jest to możliwe.

Poza konstytucją można również wyróżnić szereg instytucji, które stoją zarówno na straży obecnej kultury strategicznej, ale jednocześnie dają impuls do zmian. Wśród nich istotną rolę odgrywa Ministerstwo Spraw Zagranicznych. Reprezentuje ono interesy Japonii na zewnątrz, odpowiada za politykę wobec sąsiadów, za aktywność Japonii w takich forach międzynarodowych jak Regionalne Forum ASEAN, czy Szczyty Wschodnioazjatyckie. MSZ również odpowiada za kreowanie międzynarodowego wizerunku Japonii, w tym promocję języka i kultury oraz zaangażowanie Japonii w pomoc międzynarodową. Dział ds. Traktatów Bezpieczeństwa i dział ds. Porozumienia w Sprawie Statusu i Sił (Status and Forces Agreement) przy MSZ, koordynuje i odpowiada za implementację porozumienia wojskowego z USA. Natomiast dział ds. Międzynarodowych Stosunków Prawnych (International Legal Affairs) zajmuje się interpretacją przepisów zawartych w Japońsko-Amerykańskim Traktacie Bezpieczeństwa. ${ }^{37}$

Ministerstwo Spraw Zagranicznych ściśle współpracuje w tym obszarze z Ministerstwem Obrony. Warto podkreślić, że do 2007 r. w Japonii formalnie nie było takiego ministerstwa. Zamiast niego istniała Agencja Obrony Japonii. Od powstania, Ministerstwo Obrony zaczyna odgrywać coraz bardziej znaczącą rolę w określaniu i planowaniu strategii. $\mathrm{W}$ jego posiedzeniach uczestniczą mundurowi członkowie Sił Samoobrony, którzy biorą również udział w spotkaniach i konferencjach za granicami, co może być interpretowane jako jednym z symptomów

${ }^{37}$ A. L. Oros, Japan's Stretegic Culture..., s. 241. 
zmian w kulturze strategicznej. Podobnie jak powołanie w 2013 r. w ramach Sekretariatu Rządu instytucji, związanej z bezpieczeństwem narodowym - Rady Bezpieczeństwa Narodowego (National Security Council). ${ }^{38}$ W Radzie $1 / 3$ jej składu stanowią mundurowi członkowie Sił Samoobrony, pozostali to pracownicy MSZ i Ministerstwa Obrony. ${ }^{39}$ Może to świadczyć o wzmocnieniu roli premiera i coraz większej centralizacji.

W 2013 r. została przyjęta Narodowa Strategia Bezpieczeństwa, w której przedstawiono główne zasady, interesy, cele i wyzwania dla bezpieczeństwa narodowego Japonii. Strategiczne podejście do bezpieczeństwa Japonii powinno polegać, zgodnie ze Strategią, na: wzmacnianiu możliwości i roli Japonii, wzmocnieniu sojuszu z USA, wzmocnieniu działań dyplomatycznych i współpracy w kwestiach bezpieczeństwa $\mathrm{z}$ partnerami w celu zachowania pokoju i stabilności, aktywnych działaniach na rzecz utrzymania pokoju i stabilności w środowisku międzynarodowym, odwoływania się do wspólnych wartości, wzmocnieniu wewnętrznego poparcia dla realizacji celów bezpieczeństwa narodowego ${ }^{40}$ Rok później w oparciu o Strategię zostały przyjęte Wytyczne Narodowego Programu Obrony (National Defence Program Guidelines). Zawierały one podstawy polityki obrony Japonii. Największe dyskusje i emocje budziły zawarte w Wytycznych takie sformułowania jak: „grey zone”, rozumiane jako obszary będące źródłem niepewności i mogące zagrażać bezpieczeństwu Japonii. ${ }^{41}$ Działanie te można interpretować jako zgodę na użycie siły militarnej w odpowiedzi na sytuację, która nie dotyczy ataku bezpośredniego na terytorium Japonii. Drugie sformułowanie powtórzone ze Strategii to „proaktywny udział w utrzymaniu pokoju”, co można interpretować jako szersze zaangażowanie się Japonii w sytuację międzynarodową, wzmacnianie i rozbudowę systemu obronnego i budowę architektury obronnej. ${ }^{42}$

Strażnikiem kultury strategicznej, jak również inicjatorem zmian są same Siły Samoobrony(SS). Zbyt daleko idące zaangażowanie Japonii w ,proaktywnym utrzymaniu pokoju", może mieć określone konsekwencje. Takimi jak chociażby straty w ludziach, czy wzrost liczby rannych. Pojawiają się zatem obawy, że zmiana w kulturze strategicznej w kierunku jeszcze większego zaangażowania Japonii, doprowadzi w efekcie do spadku zainteresowania udziałem w służbie w SS, czy odpływem studentów z Akademii Obrony Narodowej. Z drugiej strony obecny premier może liczyć na poparcie w kręgach wojskowych szczególnie wśród oficerów politycznie zorientowanych. Celem uzyskania poparcia prowadzone są kampanie reklamowe, których celem jest zachowanie pozytywnego wizerunku

${ }^{38}$ Ibidem s. 242.

${ }^{39}$ www.japantimes.co.jp

${ }^{40}$ National Security Strategy, http://www.mofa.go.jp/fp/nsp/page1we_000081.html (data dostępu: kwiecień 2016)

${ }^{41}$ National Defense Program Guidelines for YF 2014 and beyond (summary) http://japan. kantei.go.jp/96_abe/documents/2013/_icsFiles/afieldfile/2013/12/17/NDPG(Summary).pdf (data dostępu: kwiecień 2016).

${ }^{42}$ Ibidem. 
Sił Samoobrony wśród społeczeństwa oraz wzmacnianie uczuć patriotycznych. Ministerstwo Obrony Japonii przygotowało w tym celu film animowany, w której bohaterem jest ptak o imieniu Bo-Emon. W trakcie filmu wyjaśnia on trójce małych dzieci, których ojciec jest pilotem myśliwca F-15, że celem Sił Samoobrony jest powstrzymanie agresji ze strony wroga i zapewnienie stabilności gospodarczej Japonii, a nie atakowanie innych państw. ${ }^{43}$

Istotna rola w kreowaniu kultury strategicznej przypada również partiom politycznym. W okresie powojennym dwie główne partie polityczne były zaangażowane w tworzenie polityki bezpieczeństwa: Partia Liberalno-Demokratyczna i Demokratyczna Partia Japonii. Pierwsza powstała w 1955 r. i z niewielkim przerwami sprawuje władzę do chwili obecnej. Wśród jej członków byli również zwolennicy polityki rewizjonistycznej, proponowali odbudowę pozycji militarnej Japonii i zajęcie należnego jej miejsca. Wśród nich był również dziadek obecnego premiera Abe, Nobusuke Kishi (1957-1960). Zdecydowaną większość stanowili jednak politycy opowiadający się za postawą antymilitarną i przyjęciu gwarancji bezpieczeństwa ze strony USA. Ostatnio ta postawa ulega stopniowej zmianie, a obecny premier wykorzystując koalicję z partią Komeito, dążąc stopniowo do uzyskania wymaganej większości, dla wprowadzenia zmian w konstytucji, co osiągnął w 2016 roku, uzyskując w lipcu wymaganą większość 2/3 w wyższej izbie japońskiego parlamentu Izbie Radców. ${ }^{44}$

O zmianie kultury strategicznej Japonii świadczy również wzrost wydatków militarnych. Japonia z roku na rok zwiększa swój budżet obronny. W grudniu 2015 r. parlament uchwalił wzrost budżetu na 1.5\% w 2016 roku, co w kwotach daje rekordową wartość 42.4 mld USD. Wydatki są znaczące, nawet jeżeli blado wyglądają przy wydatkach ChRL. Japonia zamierza zakupić też 42 myśliwce F-35 oraz samolot Osprey tilt-rotor - samolot pionowego startu i lądowania oraz 52 amfibie Szturmowe. ${ }^{45} \mathrm{~W}$ planach jest też zwiększenie sił morskich. Wybudowany została też radar na wyspie Yonagumi w odległości 108 km od Tajwanu. Planowana jest też budowa następnych, na pobliskich wyspach. Do 2020 r. premier Abe zamierza umieścić na wyspie Amami Oshima, leżącej między Kiusiu a Okinawą, ok. 500 żołnierzy. Tym samym zwiększa możliwości logistyczne SO na wypadek sytuacji kryzysowych. W sumie na wsypach na Morzu Wschodniochińskim ma stacjonować ok. 10 tyś żołnierzy japońskich. ${ }^{46}$

${ }^{43} \mathrm{https} / / /$ www.youtube.com/watch?v=YP6mMCyXFsk, (data dostępu: maj 2016)

${ }^{44} \mathrm{http}$ //www.japantimes.co.jp/news/2016/07/11/national/politics-diplomacy/upper-house-election-exit-poll-highlights-divide-over-constitutional-revision/\#.V5X31PmLRD8, (data dostępu: lipiec 2016)

${ }^{45}$ F. Gody, Japan Approves Record Defense Budget, "The Diplomat" 2015, 28 Dec., http:// thediplomat.com/2015/12/japan-approves-record-defense-budget/ (data dostępu: maj 2016)

${ }^{46}$ M. Auslin, Japan's New Realism. Abe Gets Tough, "Foreign Affairs" 2016, March/April 


\title{
WNIOSKI
}

Antymilitarystyczna kultura strategiczna Japonii jest postrzegana przez elity polityczne Japonii, jak również przez środowisko międzynarodowe jako bariera dla większego zaangażowania tego państwa w bezpieczeństwo regionalne i globalne, niezbędne przeciwdziałaniu zachwiania równowagi w regionie Azji i Pacyfiku. Jest również barierą w pogłębianiu sojuszu z USA. Niewątpliwe zmiana zostałaby przyjęta pozytywnie przez takie państwa jak Australia, Indie, Indonezja, Wietnam, czy Filipiny, negatywnie zaś przez Chiny, Rosję, czy państwa koreańskie. Prawdopodobnie utrzymanie obecnego kursu polityki zagranicznej Japonii, może w konsekwencji przyczynić się do eskalacji napięć w regionie, destabilizacji kruchych sojuszy, a w efekcie może prowadzić do konfliktów. Może też negatywnie wpływać na międzynarodowy wizerunek Japonii o osłabić w widoczny sposób zasoby soft power.

Należy podkreślić, że pomimo widocznej zmiany w kulturze strategicznej Japonii, nadal ogranicza ją, póki co, instytucjonalny antymilitaryzm.

\section{STRATEGIC CULTURE OF JAPAN}

\begin{abstract}
The purpose of the article is calling attention on the role of Japan in forming in the Asia and Pacific region new international order, by a prism of its strategic culture. Therefore, it is necessary to answer the question if by the reason of its both economic and technological might is Japan able for playing full-dimension role of world-power? Or playing that role is limited by strategic culture of Japan? What are the factors of Japan's strategic culture in the past and presently? In the paper the author verifies the following hypothesis - Japan's strategic culture is changing in spite of internal institutional antimilitarism.
\end{abstract}

Key words: strategic culture, Japan, Shinzō Abe, institutional antimilitarism, pro-active pacifism 